\title{
Analysis Of The Effect Of Non Verbal Communication On Customer Loyalty Through Emotional Response And Customer Satisfaction On Grapari Visitors In Surabaya.
}

\author{
Kartina Tansy, Ronald ${ }^{\mathrm{b}}$, Oliandes ${ }^{\mathfrak{c} *}$ \\ akartinatansy@gmail.com \\ ${ }^{a}$ Master of Management Student at Pelita Harapan University, Surabaya 60234, Indonesia \\ ${ }^{b, c}$ The Lecturer of Master of Management at Pelita Harapan University, Surabaya 60234, Indonesia
}

\begin{abstract}
Every company will do its best to compete with its competitors. There is also intense competition in the telecommunications sector in Indonesia. In 1989, the telecommunications sector was still monopolized by the government, but since 2000 based on government policies it has opened wide for the emergence of new players in the telecommunications sector. This marks the beginning of a competitive environment in the telecommunications sector. In line with globalization, the role of telecommunications is very important, society needs a faster exchange of information. In addition, developments in the information sector are now so fast and rapid, both in terms of content and the technology used to convey information. Therefore, the presence of GraPARI Telkomsel is very influential in the development of the telecommunications industry, especially in Surabaya. This study aims to analyze the effect of kinesics, proxemics, paralanguange and physical appearance variables on customer loyalty through emotional response and customer satisfaction of Telkomsel GraPARI customers in Surabaya. The sample used in this study is based on data from 105 male and female respondents, living in Surabaya, with an age limit of 18-60 years. The questionnaire was given to GraPARI Telkomsel visitors in Surabaya for the past 1 year. For processing and analyzing data in this study using SPSS 22.0. Furthermore, to tabulate the results of the respondents' research, as well as to test the research model is to use the Structural Equation Model (SEM) data analysis technique
\end{abstract}

Keywords: Kinesics, Proxemics, Paralanguage, Physical Appeareance, Customer Loyalty, Satisfaction. Emotional Response, Customer satisfaction.

\section{Introduction}

Every company certainly improves their management in order to survive and compete in the broad market. Customer satisfaction is the key to the success of a company. Consumers who get high satisfaction will have a positive impact on future customer loyalty. "The lower market growth and high competition, especially in the telecommunications sector, have made companies more inclined to try to maintain market share by focusing on retaining existing customers." (Lee, et. Al., 2001). According to Morgan and Hunt (1994), which implicitly states relationship marketing is a concept to face competition at this time. Relationship marketing is all marketing activities aimed at building, developing and maintaining future successful relationships with partnerships (researchgate.net, downloaded on July 2, 2020).

Customer relationship is a main factor for business success. Therefore, it is natural that companies and service providers place a greater focus on the performance of Customer Relationship Management. The focus is more on customers, not products or services, namely by focusing on customer needs and wanting to achieve customer satisfaction and loyalty. Customer Relationship Management is all about increasing profitability and 
it enables businesses to keep customers under control, making them feel truly part of the progress of the business (Shoniregun, et. Al., 2004).

Consumers always expect everything that is needed and expected to be available. Customer expectations come from their previous purchasing experience, advice from friends and colleagues, and promises and information from marketers and competitors, Kotler (2009). Customer expectations are believed to have a big role in determining product quality (goods and services) and customer satisfaction. Basically is a close relationship between the determination of quality and customer satisfaction. In evaluating it, customers will use their expectations as a standard or reference. Thus, it is customer expectations that are the background why two organizations in the same business can be judged differently by their customers. In the context of customer satisfaction, expectations are generally estimates or customer beliefs about what they will receive (Zeithmal, et. Al., 1993).

In an effort to retain customers, companies need to strive to create customer loyalty. However, companies need to realize that loyalty alone is not enough to guarantee the survival of the company, because loyalty does not significantly affect sales and profit. There needs to be concrete action as evidence that customers are truly loyal to the company, namely customer retention (Buttle, 2004). When a company is unable to build a strong customer relationship, the possibility that consumers will leave is commonplace. According to Singh and Khan (2012), customer retention is the activity of a sales organization in an effort to reduce customers who fail to maintain. Customer retention is started from the first time the company makes a contact with the customers until the company can establish long-term relationships with customers.

Connectivity is important, not only for the population of Indonesia to connect approximately 257 million people but also for all populations in 20 other APEC countries. This is where the information and the communication technology are playing their role. Apart from being an enabler for connectivity as well as a trigger for equitable economic growth (Ferariani, 2007). So many telecommunication operators are competing for market share (kemenpppa.go.id, downloaded on July 2, 2020).

The development of the telecommunications sector occurs globally. According to Jaya (2008) the increasing number of companies entering the industry will increase competition in the industry. The entry of new cellular operators has further increased competition in this industry. Supported by the advantages of more mobile technology, more varied operator services, more multifunctional telephone use (including the internet and social networks) and a co-branding strategy also encourages the development of the number of mobile cellular subscribers to be very fast (balitbangsdm.kominfo.go.id, downloaded on July 2, 2020).

Competition in the telecommunications industry in Indonesia is one of the most highly competitive when compared to the telecommunications industry in other countries. If other countries only have 3 to 5 operators, Indonesia has 11 operators that compete with each other to win customers. End of 2019, Opensignal released its mobile network experience report. There are five cellular operators analyzed by Opensignal for their cellular experience, namely Hutchison 3 Indonesia (Tri), Indosat Ooredoo, Smartfren, Telkomsel, and XL Axiata with number one ranking controlled by Telkomsel. According to Opensignal, Telkomsel controls six of the seven metrics that the global wireless coverage mapping company analyzes. The six metrics in question are Video Experience, Voice App Experience, Download Speed Experience, Upload Speed Experience, Latency Experience and 4G Coverage Experience (opensignal.com, downloaded July 2, 2020).

PT. Telkomsel is the largest cellular telecommunications operator in Indonesia. In running its business, Telkomsel provides cellular telecommunication services of the GSM type (Global System for Mobile), which is a type of global cellular operator throughout the world. Telkomsel company announced that the number of its users has reached 131.5 million customers throughout Indonesia. That number is up from 125 million users at the end of 2012. Telkomsel recorded revenue growth of 10.4 percent from year to year, which was supported by growth in broadband data, while EBITDA and net income grew by 11.1 percent and 11.9 
percent respectively. to the year. (telkomsel.com, downloaded on July 2, 2020).

Telkomsel has the largest number of users compared to other cellular operator companies. This has led to intense competition which requires them to observe changes in consumer behavior in their market segments. The aim is to improve their marketing strategies and compete in creating consumer- oriented products, for example by providing complete features and providing the best service, so a strategy is needed to obtain consumer attention. as the market leader of cellular telecommunication operator companies in Indonesia, Telkomsel is required to continue to evaluate and improve their standards in order to be able to survive in their position. It is not impossible if one day Telkomsel can be defeated by its competitors (databoks.katadata.co.id, downloaded on July 2, 2020).

Customer loyalty is the key to keep the company alive in its business. Finding new customers is difficult, but it is much more difficult to keep existing customers. Competing for customer loyalty is the main thing in winning the competition. Customer loyalty is the pinnacle of achievement for business people. Satisfied and loyal customers tend to be good spreaders of information about the products in use. High satisfaction or pleasure which tends to cause customers to behave positively, emotional attachment to the brand, so the result is high customer loyalty. Even though they are not paid by the company, they will recommend products from the company (Lovelock \& Wright, 2002).

According to Parasuraman, et. al., (1990) in Kotler (2003) Conceptual Model of Service Quality, they formulate a service quality model to meet customer satisfaction. According to this model, there are five gaps (gaps) that make the company unable to provide quality service to customers. Customer Gap is the difference between customer perception and customer expectations (between customer perception and customer expectation). Consumer Perception is a subjective assessment by customers of their experience consuming goods or services. Customer expectations are standards or references to customers with experience in consuming goods or services. Consumer perceptions and consumer expectations should be identical, but in reality, there is a fairly large gap. It is the marketer's job to build a bridge between the two and / or make efforts to narrow or close the gap that occurs.

In general, customer satisfaction (customer satisfaction) is the feeling of happy or disappointed someone that arises from comparing the product's perceived performance (or results) against their expectations. If performance fails to meet expectations, customers will be dissatisfied. If the performance is as expected, the customer will be satisfied. If performance exceeds expectations, customers will be very satisfied (Kotler \& Keller, 2003).

\section{Litterature Review}

2.1 Theories and Hypotheses

\subsubsection{Kinesics}

Solihin (2010) states in nonverbal communication, kinesics or body movements include eye contact, facial expressions, gestures, and body postures. Based on Sundaram and Webster's (2000) research, this study divides the characteristics of nonverbal communication into kinesics such as movement; proxemics, meaning proper space is required for communication; paralanguage, such as voice and manner and speed of speech and physical appearance, such as physical attractiveness, clothing, and hairstyle. Kinesics is also composed in detail by Birdwhistell (1952), and it means communication behavior in expressing opinions with symbols of sight, gestures and posture (Argyle, 1994).

Hypothesis 1: Kinesics has a significant effect on the Emotional Response. 


\subsubsection{Proxemics}

Proxemics is the way humans use space, and the influence of space in communication is called Proxemic (Edward T. Hall, 2005). Burgoon et al. (1990) study found that the right distance between employees and customers results in favorable evaluations of the customer towards the company. Each culture has its own characteristics in conceptualizing space, whether in the form of a house, arrangement in the house or outside the house or how to socialize with one another (Riswandi, 2009). According to Webster (2000) Proxemics means the right space required for communication between employees and customers. Checking when a customer is watching an approaching employee indicates that an appropriate distance, neither too far nor too close, must be maintained

Hypothesis 2: Proxemics has a significant effect on the Emotional Response.

\subsubsection{Paralanguage}

Paralanguage is a form of direct persuasion through use incentives can be arranged to stimulate immediate product purchases and increase the number of goods purchased by customers (Tjiptono, 2015). The service provider's movement or posture may be a clue by which customers understand that the former is caring and sincere (Knapp, 1980; Sundaram and Webster, 2000). Every member of the body such as the face, hands, head, feet and even all of our limbs can be used to communicate symbolically (Riswandi, 2009). Paralanguage studies various human voices in addition to formal language, forms the basis for understanding content intensity and emotional state through pseudo language and influences the level of customer understanding and employee persuasion (Burgoon, 1979; Argyle, 1983)

Hypothesis 3: Paralanguage has a significant effect on the Emotional Response.

\subsubsection{Physical Appearance}

According to Patzer (1985), "Physical attractiveness is the notion of information that involves an indirect, prevalent and definite effect that produces a definite and best pattern of difference". The celebrity endorser's physical attractiveness gets great praise from a source to grab the attention of audiences in both electronic and print media. Physical appeareance definitely affects consumer behavior towards products and services. (Ohanian, 1991). Kim and Chung (2011) argue that if someone cares about self appearance, it will cause attitudes to increase by choosing suitable products to increase self-beauty. When consumers realize that a good appearance will have an impact on increasing buying attitudes

Hypothesis 4: Physical Appearance has a significant effect on the Emotional Response.

\subsubsection{Emotional Response}

According to Park et al., (2005) Emotions is an effect of mood which is an important factor for consumers in decisions about purchases to be made. According to Chang et al., (2014) Positive Emotion can be caused by a person's previous moods such as excitement, and reactions to the environment (desired product or promotion). Positive Emotion can help increase the tendency of consumers to buy unplanned, positive emotions consist of emotional attachment, curiosity, and satisfaction when using new products (Sharma and Kaur, 2015).

Hypothesis 5: Emotional Response has a significant effect on the Customer Satisfaction. 


\subsubsection{Customer Satisfaction}

According to Kotler and Keller (2016), Customer satisfaction is the feeling of being happy or disappointed by someone that comes after comparing the performance (results) of the product that is thought of against the expected performance. Satisfaction is also an attitude resulting from a comparison of performance expectations and perceived performance from the service experience. This is known as the disconfirmation of expectations (Hamilton, et al., 2016). The key to customer satisfaction lies in identifying and anticipating customer needs and especially being able to satisfy them. Companies that are able to understand and satisfy customer needs quickly generate greater profits than companies that fail to understand and satisfy them (Dominici \& Guzzo, 2010).

Hypothesis 6: Customer Satisfaction has a significant effect on Customer Loyalty.

\subsection{Research Model}

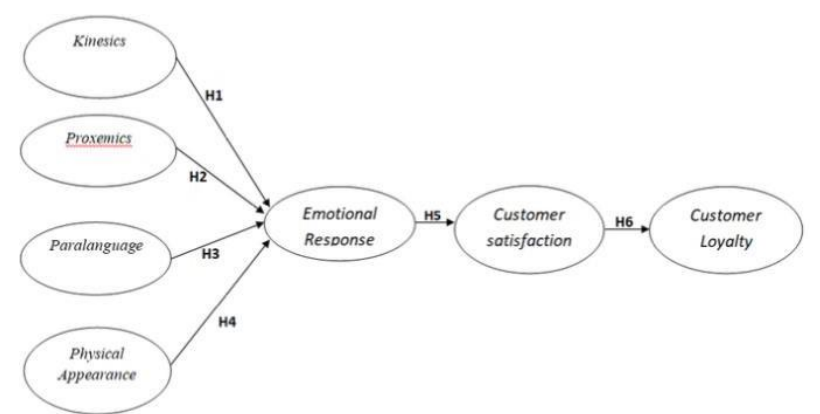

Figure 2.1: The Framework of Research Model

\section{Research Methods}

This research is causal research, because it is used to develop existing research models to test the research hypotheses that are determined based on literature review to answer the problems identified in the previous chapter. The research method used in this study is a quantitative method, where this method is a scientific approach to managerial and economic decision making. The method used in this study will refer to references that can carry out a simultaneous analysis process associated with a multi-variable research model, the Structural Equation Model (SEM). The program used is the AMOS 22.0 software program. This chapter describes the object of research directed at analyzing models about the relationship between variables to understand the factors that influence Customer Loyalty from GraPARI customers on Surabaya. The sampling method used in this research is non- probability sampling. This study uses a questionnaire as the main tool in data collection. In this study, researchers will use a snowball sampling technique, where researchers determine respondents who will help researchers to distribute and fill out questionnaires. The area used as a place for distributing questionnaires was the Surabaya city, so that respondents were selected according to the criteria determined in this study. The characteristics of the respondents determined are men and women aged 18-60 years where the age is an early adulthood (Kotler and Armstrong, 2010), domiciled in Surabaya and visiting GraPARI telkomsel surabaya at least in the last 1 year. There are 21 indicators used in this study indicators, from the number of existing indicators, the minimum number of samples used is 100-200 respondents, and for this research the number of respondents is 105 people. The sample used for research was 105 espondents. Data collection is done by distributing questionnaires to respondents in accordance with the characteristics of the sample that has been described previously. After completing the questionnaire, the 
respondent returns the questionnaire that has been filled out and will then be selected by the researcher. The selected questionnaire is a questionnaire that is completely filled out and according to the filling instructions. After selection, the selected questionnaire will be further processed. After the data is tabulated, then the research model will be tested using AMOS software version 22.0. The questionnaire in this study will be divided into two parts. The first part contains questions to get general information about the respondent himself that is useful to determine the suitability of the characteristics of the respondents with the sample criteria. The second part contains questions to obtain research data and analyze the effect of Kinesics, Proxemics, Paralanguage, Physical Appearance, on Customer Loyalty through Emotional Response and Customer Satisfaction. The scale used in this study is a Likert Scale, where the answer is provided at intervals from $1=$ Strongly Disagree (STS) to 5=Strongly Agree (SS). Statements are made using a scale of 1-5 to obtain internal data.

\section{Results and Discussion}

4.1 Assessment of Measurement Model

Table 4.1: Regression Weights Full Structural Equation Model

\begin{tabular}{|c|c|c|c|c|c|}
\hline & Estimate & S.E & C.R. & $\mathrm{P}$ & $\begin{array}{c}\text { Std. } \\
\text { Estimate }\end{array}$ \\
\hline Emotional Response $\leftarrow$ Kinesics & 0,185 & 0,071 & 2,603 & 0,009 & 0,242 \\
\hline Emotional Response $\leftarrow$ Proxemics & 0,759 & 0,191 & 3,975 & $* * *$ & 0,542 \\
\hline Emotional Response $\leftarrow$ Paralanguage & 0,543 & 0,141 & 3,861 & $* * *$ & 0,436 \\
\hline Emotional Response $\leftarrow$ Physical Response & 0,363 & 0,116 & 3,118 & 0,002 & 0,331 \\
\hline Customer Satisfaction $\leftarrow$ Emotional Repsonse & 0,870 & 0,133 & 6,525 & $* * *$ & 0,682 \\
\hline Customer Loyalty $\leftarrow$ Customer Satisfaction & 0,465 & 0,098 & 4,723 & $* * *$ & 0,538 \\
\hline Y5 $\leftarrow$ Customer Satisfaction & 0,675 & 0,078 & 8,664 & $* * *$ & 0,746 \\
\hline $\mathrm{X} 1 \leftarrow$ Kinesics & 1.000 & & & & 0,844 \\
\hline $\mathrm{X} 2 \leftarrow$ Kinesics & 0,699 & 0,115 & 6,100 & $* * *$ & 0,647 \\
\hline $\mathrm{X} 3 \leftarrow$ Kinesics & 0,892 & 0,124 & 7,217 & $* * *$ & 0,824 \\
\hline $\mathrm{X} 4 \leftarrow$ Proxemics & 1,000 & & & & 0,583 \\
\hline X5 $\leftarrow$ Proxemics & 1,322 & 0,268 & 4,929 & $* * *$ & 0,756 \\
\hline X6 $\leftarrow$ Proxemics & 1,523 & 0,297 & 5,122 & $* * *$ & 0,756 \\
\hline $\mathrm{X} 7 \leftarrow$ Paralanguage & 1,000 & & & & 0,704 \\
\hline $\mathrm{X} 8 \leftarrow$ Paralanguage & 1,118 & 0,225 & 4,974 & $* * *$ & 0,672 \\
\hline X10 $\leftarrow$ Physical Appearance & 1.000 & & & & 0,692 \\
\hline X11 $\leftarrow$ Physical Appearance & 1,372 & 0,205 & 6,685 & $* * *$ & 0,852 \\
\hline $\mathrm{X} 12 \leftarrow$ Physical Appearance & 1,249 & 0,195 & 6,400 & $* * *$ & 0,759 \\
\hline Y2 $\leftarrow$ Emotional Response & 0,978 & 0,107 & 9,172 & $* * *$ & 0,789 \\
\hline Y3 $\leftarrow$ Emotional Response & 0,964 & 0,107 & 9,025 & $* * *$ & 0,764 \\
\hline Y1 $\leftarrow$ Emotional Response & 1,000 & & & & 0,799 \\
\hline X9 $\leftarrow$ Paralanguage & 1,095 & 0,236 & 4,638 & $* * *$ & 0,677 \\
\hline Y8 $\leftarrow$ Customer Loyalty & 0,993 & 0,118 & 8,384 & $* * *$ & 0,787 \\
\hline Y6 $\leftarrow$ Customer Satisfaction & 0,927 & 0,124 & 7,503 & $* * *$ & 0,702 \\
\hline Y4 $\leftarrow$ Customer Satisfaction & 1,000 & & & & 0,867 \\
\hline Y9 $\leftarrow$ Customer Loyalty & 1,146 & 0,135 & 8,499 & $* * *$ & 0,822 \\
\hline Y7 $\leftarrow$ Customer Loyalty & 1,000 & & & & 0,824 \\
\hline
\end{tabular}


C.R. for each relationship between the variables tested is shown in table 4.1. These results show that of the 6 proposed hypotheses, there are 6 accepted hypotheses that have a value of C.R. above 2.00

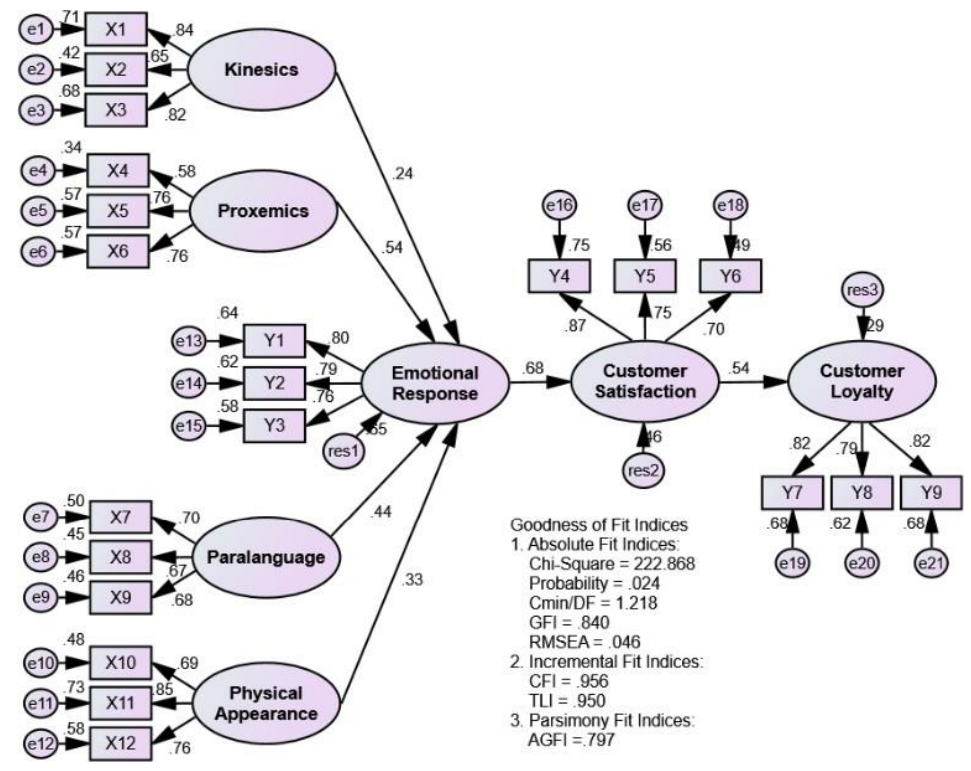

Figure 4.1 Full Structural Equation Model

Source: Amos 22.0 Analysis Result, 2020

\subsection{Hypotheses Testing}

Table 4.4: Summary of Testing Results.

\begin{tabular}{|l|l|}
\hline Hypotheses & Analysis \\
\hline H1: Kinesics has a significant effect on the Emotional Response. & Accepted \\
\hline H2: Proxemics has a significant effect on the Emotional Response. & Accepted \\
\hline H3: Paralanguage has a significant effect on the Emotional Response. & Accepted \\
\hline H4: Physical Appearance has a significant effect on the Emotional Response. & Accepted \\
\hline H5: Emotional Response has a significant effect on the Customer Satisfaction. & Accepted \\
\hline H6: Customer Satisfaction has a significant effect on Customer Loyalty. & Accepted \\
\hline
\end{tabular}

\subsection{Discussion}

\subsubsection{The effect of Kinesics on Emotional Response}

The first hypothesis shows that Kinesics has a significant positive effect on Emotional Response with a regression coefficient value of 0.230 with a CR value of 2.598 which indicates that this hypothesis is accepted. This explains that Kinesics has a significant effect on GraPARI customers, because the services provided by GraPARI are better than those of other cellular service providers. For products owned by 
GraPARI also have more services. better than other cellular providers. This must be maintained in a way that employees can be provided with friendly service training such as how to greet customers who come to the shop by giving a smile and greeting welcome or by adding a slogan to give GraPARI's own distinctive characteristics. Then also by reviewing the services provided by GraPARI which can then be given attractive prizes to customers who have participated so that GraPARI can evaluate the services provided and find out the services that customers want.

\subsubsection{The effect of Proxemics on Emotional Response}

The first hypothesis shows that Proxemics has a significant positive effect on Emotional Response with a regression coefficient value of 0.511 with a value of C.R. 3.648 which indicates that this hypothesis is accepted. This explains that the way employees at GraPARI serve customers well where everything is communicated with customers so as to provide comfort. When you want to improve consumer Proxemics towards GraPARI, the thing to pay attention to is to make consumers feel comfortable with the services provided as employees can position themselves well when dealing with customers. To improve it, the company can provide training to employees about good service in order to provide comfort for customers, starting with knowing and studying all the service standards that should be and understanding correctly how the procedure for solving problems when there are complaints from customers. Proxemics GraPARI is getting higher in the form of employee services who can position themselves well and provide customers comfort when visiting, of course, will increase Emotional Response in the form of positive emotions of customers as expected so as to attract consumers to visit again.

\subsubsection{The effect of Paralanguage on Emotional Response}

The first hypothesis shows that Paralanguage has a significant positive effect on Emotional Response with a regression coefficient value of 0.416 with a value of C.R. 3,866 which indicates that this hypothesis is accepted. This explains that the services provided at GraPARI are in accordance with customer desires. When the GraPARI wants to improve customer Paralanguage to GraPARI, the main thing to pay attention to is to impress consumers with the services provided, such as explaining clearly and in detail and not being hasty about the product consumers are asking for and responding and helping quickly to problems reported when consumers filed a complaint. To improve it, the company can provide training to employees regarding good service such as when serving customers, GraPARI employees speak with clear articulations of words, soft tones and are not rushed. When customers feel that the information received is clear and the services provided are satisfying, it will certainly increase the Emotional Response in the form of positive emotions from the customer.

\subsubsection{The effect of Physical Appeareance on Emotional Response}

The first hypothesis shows that Physical Appeareance has a significant positive effect on emotional response with a regression coefficient value of 0.263 and a value of C.R 2.398 which indicates that this hypothesis is accepted. This explains that Physical Appeareance has a significant effect on GraPARI customers, because the Physical Appearance of GraPARI employees can affect the feelings or emotions of customers. Where employees will feel comfortable with what they see. This can be improved by GraPARI by holding regular briefings every morning to double check the tidiness of employees, from hair to clothes. Providing standards also for employees with haircuts and clothes.

\subsubsection{The effect of Emotional Response on Customer satisfaction}

The first hypothesis shows that Emotional Response has a significant positive effect on Customer Satisfaction with a regression coefficient value of 0.699 with a value of C.R. 6,521 which indicates that this hypothesis is 
accepted. This explains that when you want to increase customer Emotional Response to GraPARI, the main thing to pay attention to is to continue to maintain service that exceeds customer expectations, make customers feel comfortable and want to visit again, besides providing service information as promoted to customers so that customers feel services obtained are in accordance with what is paid.

\subsubsection{The effect of Customer satisfaction on Customer Loyalty}

The first hypothesis shows that Customer Satisfaction has a significant positive effect on Customer Loyalty with a regression coefficient value of 0.547 with a C.R value of 4.721 which indicates that this hypothesis is accepted. This explains that when the GraPARI wantS to increase Customer Satisfastion, the main thing to pay attention is to keep consumers comfortable with the services provided, offer attractive and quality services and products, and provide products and services that exceed customer expectations. To increase it, GraPARI can provide a bonus such as special GraPARI merchandise for customers who have faithfully used the product and visited GraPARI, then can give credit vouchers or lucky draws at certain events. So that it will increase customer satisfaction and come back again to GraPARI.

\section{Conclusion}

This study provides evidence that the Kinesics significantly affected Emotional Response, Proxemics significantly affected Emotional Response, Paralanguage significantly affected Emotional Response, Physical Appearance significantly affected Emotional Response, Emotional Response significantly affected Customer Satisfaction, Customer Satisfaction significantly affected Customer Loyalty.

\subsection{Managerial Implications}

Table 5.1: Managerial Implications

\begin{tabular}{|l|l|}
\hline Current Research & Managerial Implications \\
\hline $\begin{array}{l}\text { Customer satisfaction is one } \\
\text { of the elements that is the } \\
\text { focus in the process of } \\
\text { increasing customer loyalty. }\end{array}$ & $\begin{array}{l}\text { Implementing a different strategy from competitors, for example by } \\
\text { providing a more attractive product discount strategy or implementing } \\
\text { better customer service than competitors. So that indirectly will affect the } \\
\text { interest of customers to come to GraPari and think that visiting GraPARI } \\
\text { is the right choice because the products, services and prices that } \\
\text { GraPARI provide are better than other cellular providers. } \\
\text { Providing bonuses such as special GraPARI merchandise for visiting } \\
\text { customers who are loyal to the service, then periodically updating the } \\
\text { GraPARI atmosphere so that customers feel comfortable when visiting. } \\
\text { So that with services that exceed customer expectations can increase } \\
\text { customer satisfaction with GraPARI. }\end{array}$ \\
\hline $\begin{array}{l}\text { Emotional response is one } \\
\text { element that is the focus } \\
\text { of the process to improve } \\
\text { customer satisfaction. }\end{array}$ & $\begin{array}{l}\text { How information can arrive and attract consumers' attention, and how } \\
\text { customers can be entertained by the services provided by GraPARI. Can } \\
\text { be done by giving a speech in the room so that it can entertain customers } \\
\text { who are waiting in line. } \\
\text { Adding services at GraPARI where consumers will get free snacks in the } \\
\text { waiting area, can also provide illustrator advertisements in the waiting } \\
\text { room area so that customers still feel happy even though they have to } \\
\text { wait in line. So that customers will feel GraPARI's service exceeds }\end{array}$ \\
\hline
\end{tabular}


expectations and are happy to visit again.

- Improving the quality of service and products provided to customers, such as the way employees serve customers to the information or products received by customers must exceed expectations so that positive emotions from customers due to appropriate service.

Proxemics is one element that becomes the focus in the process of increasing Emotional Response

Paralanguage is one of the elements that is the focus in the process of increasing Emotional Response

Physical Appearance is one of the elements that is the focus in the process of increasing Emotional Response elements that is the focus in the process to increase Emotional Response
- By continuing to maintain and improve service quality to provide comfort for customers that is visiting GraPARI so that customers give positive emotions wanting to visit again because the services provided are in accordance with the wishes of the customer.

- Continue to maintain the service that has been obtained by customers so that customers give positive emotions to want to keep visiting GraPARI with the services provided according to customer wishes.

- In this case, GraPARI can provide training for employees to be able to know and explain GraPARI's information properly and clearly to hear.

- Improving the quality of services provided by keep training the employees to be able to explain the information properly and not in a hurry so that it can be conveyed properly to customers. In addition, GraPARI can also provide an assessment sheet to each customer, where when a customer has visited GraPARI, the customer can assess the services provided by existing employees.

- Improve the appearance of employees by providing information about the standards set by the company, namely by providing regular training to employees regarding performance standards and then conducting briefings or directions to each employee. So that employees can meet the appearance standards desired by consumers when visiting.

- Continue to improve the knowledge and abilities of employees by providing training on operational standards and providing warnings or warnings for those who do not comply with the established standards.

- With an active role of employees to carry out all the standards that have been set, GraPARI's Standard Operating Procedures (SOPs) must be implemented properly by all employees, so that they can provide the best service to GraPari customers.

- Improve employee service to customers so that they can provide better service attitudes by providing employee training and continuing to instill service standards provided. So that with a friendly employee attitude when serving can create a positive customer mood and make customers want to return to visit GraPARI.

- Conducting training or training accompanied by practice so that employees can really understand the standard signs that must be done. Because cues in service are very influential on customer emotions, when it is considered that the signals made are impolite, they will cause negative emotions to customers. So here employees must pay attention to cues in service in order to generate positive emotions from customers. 


\subsection{Recommendation}

Looking at the results of existing research where there are still many limitations to the research conducted by the author, the recommendations that can be submitted by the author are as follows:

- Looking at the research object that only takes GraPARI Telkomsel customer respondents, it is hoped that the next research using a limited or limited model can be applied to different objects to get more general results on the factors that affect Customer Loyalty.

- Further research is expected to complement the variables that already exist in this study so that it can further enhance the understanding of the factors that influence customer loyalty, such as brand image, manufacturing quality and word of mouth.

- Further research can be developed by linking the factors that influence customer loyalty based on customer experience. Future research can also expand the scope of respondents to be researched, or conduct their research in a different area from the current research. So that further research carried out provides a broad picture of Customer Loyalty.

- In addition, it is expected to also be able to use the Lisrel Structural Equational Model (SEM) software in future research.

\section{References}

Nielsen, C. 2007. Survei of Consumer Behaviour and Perception Toward Modern Retail and Traditional Trade Channels. Jakarta: Departemen Perdagangan Indonesia.

Apriansya Jaya Putra, 2008, “Pengukuran kinerja SDM perusahaan”, Universitas Muhammadiyah Surakarta.

Buttle, Francis. 2004. Customer relationship Management Concept and Tools. Elsevier Ltd. Ferariani, Y. 2007. Analisis Kinerja PT Telekomunikasi Indonesia TBK Dibandingkan Dengan PT

Indosat TBK Dengan Menggunakan Analisis Laporan Keuangan Dan Penilaian Harga Wajar Saham [tesis]. Fakultas Ekonomi, Universitas Indonesia, Jakarta.

Handi, Irawan. 2004. Indonesia Customer Satisfication Index. Frontier.

Hasan A Abbas. 2013. Quality as Determinant Factor of Customer Satisfaction: Case Study of Zain-Kuwait. Volume: 5, 182-189.

H.S. Jung, H.H. Yoon. 2011. The effects of nonverbal communication of employees in the family restaurant upon customers' emotional responses and customer satisfaction. International Journal of Hospitality Management 30: 542-550

Hennig-Thurau, T. and U. Hansen, 2002. "Relationship Marketing: Some Reflections on the State-of- the-art of the Relational Concept.” In T. Henning-Thurau and U. Hansen (Eds). Relationship Marketing: Gaining Competitive Advantage through Customer Satisfaction and Customer.

Kotler, Philip.2003. Manajemen Pemasaran. Edisi kesebelas, Jakarta: Indeks kelompok Gramedia. Kotler, Philip. (2009). Manajemen Pemasaran, Edisi 13. Jakarta: Erlangga.

Kotler, Philip dan Keller, 2007, Manajemen Pemasaran, Jilid I, Edisi Kedua belas, PT. Indeks, Jakarta.

Lee, J., Lee, J., \& Feick, L. (2001). The impact of switching costs on the customer satisfaction-loyalty link: 
Mobile phone service in France. Journal of Services Marketing, 15, 35-48

Lovelock and Wright, 2002, Principles of Service Marketing and Management, 2nd edition, Prentice Hall.

Mayer, R.C., Davis, J. H., dan Schoorman, F. D., 1995. An Integratif Model of Organizational Trust, Academy of Management Review, 30 (3): 709-734.

Mulyana, Deddy. 2012. Ilmu Komunikasi Suatu Pengantar. Bandung: PT Remaja Rosdakarya.

Singh Roopa dan Khan Imran Akhtar (2012). An approach to increase Customer Retention and Loyality in B2C World International Journal of Scientific and Research Publications, Volume 2, Issue 6.

\section{Appendix}

Table 6.1: The Items List Used in the study

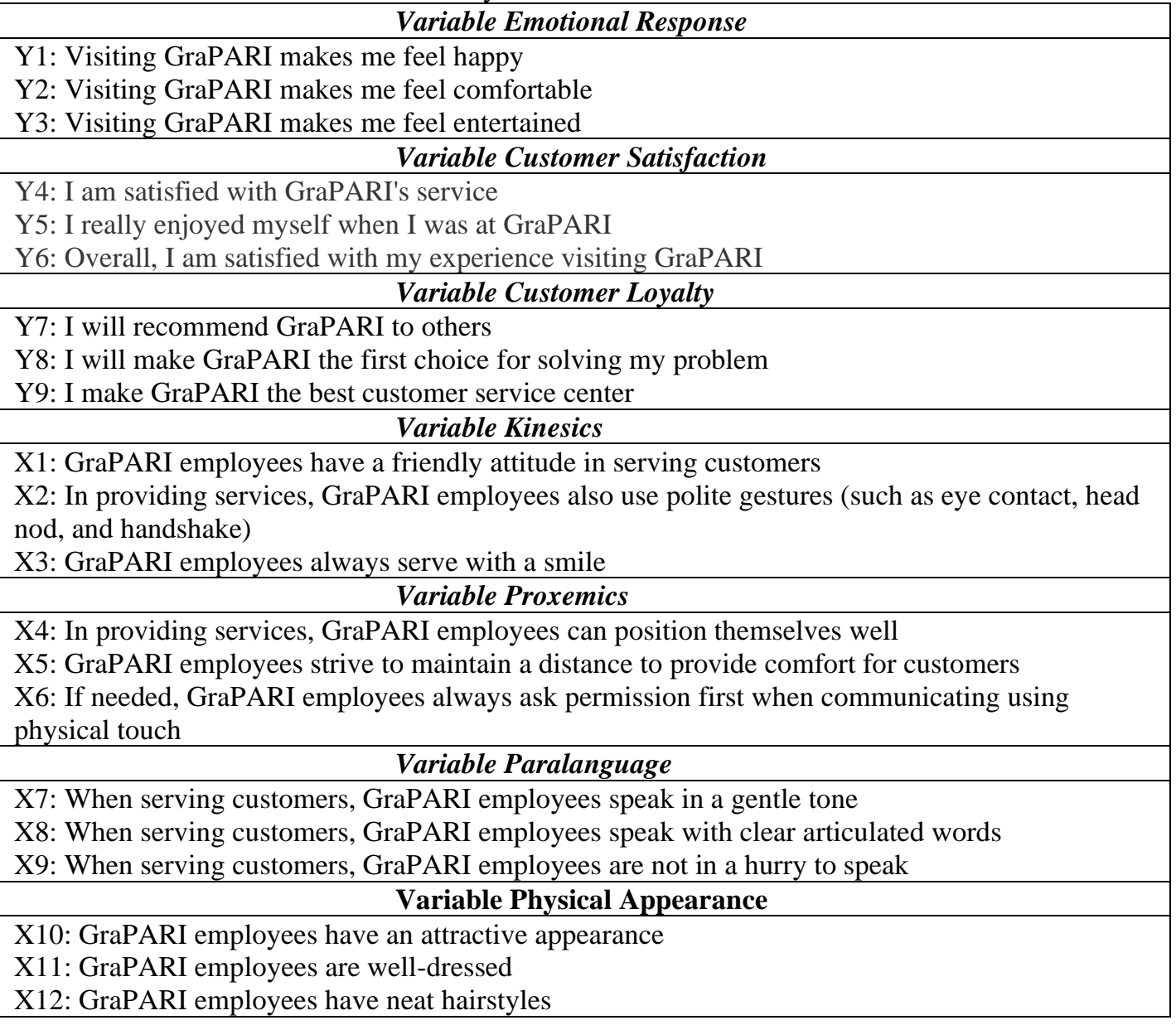

